\title{
Intraosseous meningioma mimicking a metastasis
}

\author{
Vanessa Tang, ${ }^{1}$ Maggie Lam, ${ }^{2}$ Annie Lai ${ }^{3}$
}

${ }^{1}$ EBNS, Berkeley, California, USA

${ }^{2}$ Department of Pathology, Alta Bates Medical Center, Berkeley, California, USA

${ }^{3}$ Department of Radiology, Alta Bates Medical Center, Berkeley, California, USA

\section{Correspondence to}

Vanessa Tang, g2tang@yahoo.com

Accepted 23 October 2014

\section{DESCRIPTION}

In an elderly woman with a history of malignancy, a skull lesion is most often thought of as metastasis. Bone involvement is found in $70 \%$ of postmortem examinations of patients with cancer. ${ }^{1}$ The discovery of presumed metastatic disease portends a poor prognosis, especially in the elderly and may direct care towards hospice. This case highlights a benign mimic of metastatic disease.

We present a case of an 82-year-old woman with a history of breast cancer 8 years ago who presents with increasing confusion and worsening gait. She had undergone a mastectomy with axillary lymph node dissection followed by radiation. She denied

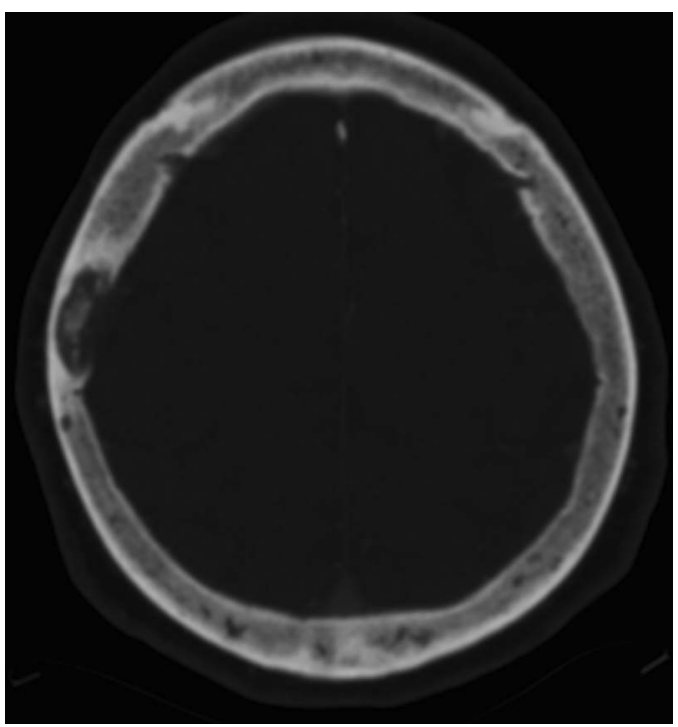

Figure 1 A non-contrast CT of the head demonstrating an osteolytic mass in the right parietal bone.

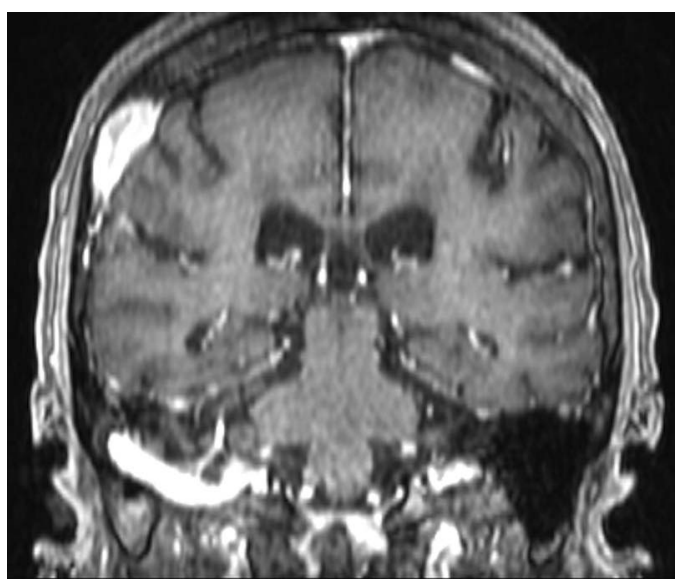

Figure 2 The MRI showing a lytic lesion with enhancing soft tissue component in the right parietal bone.

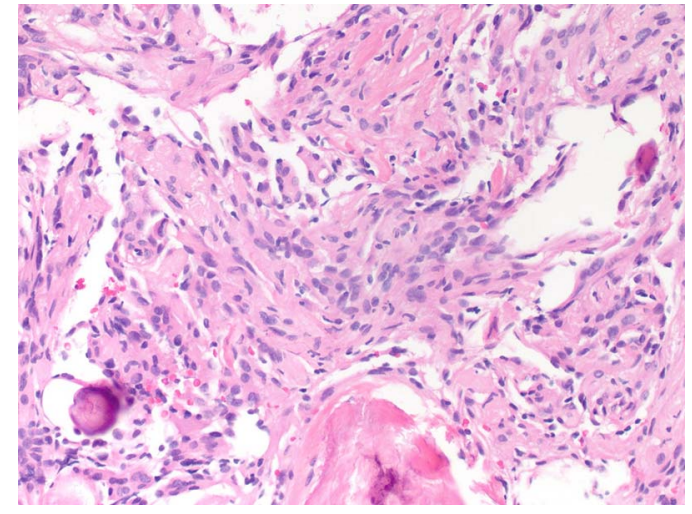

Figure 3 Pathology reveals monotonous cells with round to oval nuclei, inconspicuous nucleoli and pink syncytial cytoplasm forming vague swirls.

Psamommatous calcifications were noted.

headache or focal neurological deficits. On examination, she exhibited poor attention and memory but her examination was otherwise non-focal.

Imaging by CT and MRI demonstrated an osteolytic mass in the right parietal bone (figures 1 and 2). A positron emission tomography (PET) CT failed to show any evidence of a hypermetabolic lesion. Cancer antigen 15-3 was within normal range. A biopsy revealed a meningothelial meningioma (figure 3). Her waxing-and-waning clinical course over the subsequent 10 months suggests dementia as the primary diagnosis.

Intraosseous meningiomas are rare and are thought to arise from trapping of arachnoid cells within the developing calvaria. Less than 20 cases have been reported and in only two other cases did they mimic a metastasis. ${ }^{2} 3$ Serial imaging could have been a reasonable alternative to a biopsy. In this case, biopsy provided a definitive conclusion that facilitated planning for the patient's care.

\section{Learning points}

- Intraosseous meningioma should be considered in the differential diagnosis of a lytic skull lesion.

- In the setting of otherwise quiescent systemic disease, a negative positron emission tomography CT and a solitary lesion intraosseous meningioma should be considered.

- A biopsy is a low-risk alternative to serial imaging.

Acknowledgements The authors would like to acknowledge Gordon Tang, MD, who provided editorial assistance. 
Contributors VT collected case details. ML reviewed the pathology report. AL reviewed the radiology report.

Competing interests None.

Patient consent Obtained.

Provenance and peer review Not commissioned; externally peer reviewed.

\section{REFERENCES}

1 Coleman RE. Clinical features of metastatic bone disease and risk of skeletal morbidity. Clin Cancer Res 2006;12(Suppl):3243-9.

2 Cheng $\mathrm{HT}$, Chang $\mathrm{CH}$, Chio CC, et al. Atypical intraosseous osteolytic meningioma mimicking calvarial metastasis. Formosan J Surg 2012;45:69-72.

3 Yener U, Bayrakli F, Vardereli E, et al. Intradiploic meningioma mimicking calvarial metastasis: case report. Turk Neurosurg 2009;19:297-301.

Copyright 2014 BMJ Publishing Group. All rights reserved. For permission to reuse any of this content visit http://group.bmj.com/group/rights-licensing/permissions.

BMJ Case Report Fellows may re-use this article for personal use and teaching without any further permission.

Become a Fellow of BMJ Case Reports today and you can:

- Submit as many cases as you like

- Enjoy fast sympathetic peer review and rapid publication of accepted articles

- Access all the published articles

- Re-use any of the published material for personal use and teaching without further permission

For information on Institutional Fellowships contact consortiasales@bmjgroup.com

Visit casereports.bmj.com for more articles like this and to become a Fellow 